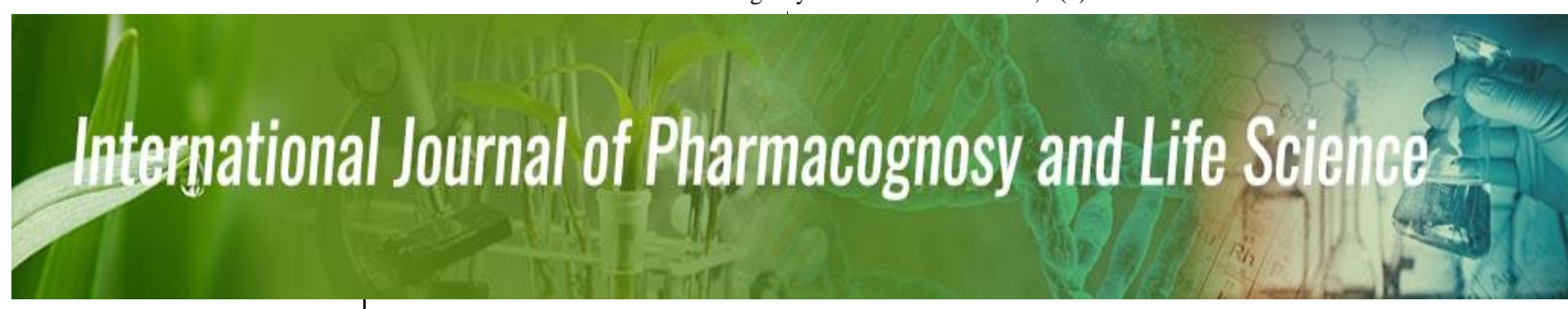

E-ISSN: $2707-2835$

P-ISSN: 2707-2827

IJPLS 2020; 1(1): 27-32

Received: 18-11-2019

Accepted: 21-12-2019

Kolhe Rohini C

T.V.E.S. Hon. Loksevak Madhukarrao Chaudhar College of Pharmacy, Jalgaon, Maharashtra, India

Dr. Chaudhari Rajesh Y T.V.E.S. Hon. Loksevak Madhukarrao Chaudhari College of Pharmacy, Jalgaon, Maharashtra, India
Corresponding Author: Kolhe Rohini C

T.V.E.S. Hon. Loksevak Madhukarrao Chaudhari College of Pharmacy, Jalgaon, Maharashtra, India

\section{Comprehension of Phytochemical and pharmacological study of Kigelia Africana (Bignoniaceae)}

\section{Kolhe Rohini C and Dr. Chaudhari Rajesh Y}

DOI: $\underline{\text { https://doi.org/10.33545/27072827.2020.v1.i1a.6 }}$

Abstract

People thorough out the world use medicinal plants to treat different ailments. Kigelia Africana (Bignoniaceae), commonly known as African sausage tree, is a medicinal plant traditionally used for the treatment of numerous diseases. Kigelia Africana is a deciduous tree, $20-30 \mathrm{~m}$ tall and $65 \mathrm{~cm}$ in diameter. The plant is described to have a widespread range of therapeutic activities, such as antidiabetic, anticancer, antimalarial, antibacterial, analgesic antileprotic, and antidiarrhoeal, antiinflammatory, antiurolithiasis, antioxidant, etc. The whole plants can be broadly studied for further future potential. The review will provide the information of Kigelia Africana on the account of Pharmacognostic, phytochemical and pharmacological study in a similar way.

Keywords: Bignoniaceae, Kigelia Africana, Pharmacognostic, Phytochemical, medicinal plants.

\section{Introduction}

Medicinal plants have been extensively used in traditional medicine and worldwide ethnomedicine. In current years, many researchers have focused on medicinal plants resulting from natural products because of their wide range of therapeutic significance [1]. Though there are excessive advances of modern scientific medicine, traditional medicine is still the main form of treating ailments of people in developing countries like India, even between those to whom western medicine is available, the number of people using one form or another of balancing of alternative medicine is rapidly increasing global. The greater knowledge of the metabolic process and the effect of plants on human physiology has widened the field of application of medicinal plants ${ }^{[2]}$. The current review is the attempt to explore one of the important traditional medicinal plants for its Pharmacognostic, Phytochemical and pharmacological aspects.

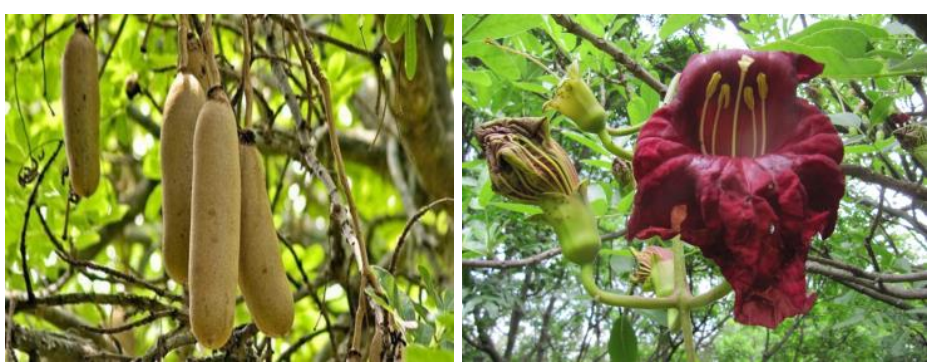

Fig 1: Fruits and Flower of Kigelia Africana plant

\section{Taxonomy}

Botanical classification ${ }^{[3]}$ :

Kingdom : Plantae, Subkingdom : Tracheobionta, Super-division : Spermatophyta, Division : Magnoliophyta, Class : Dicotyledons, Subclass : Asteridae Order : Scrophulariales Family : Bignoniaceae, Genus : Kigelia, Species : pinnata (Lam.) Benth.

Vernacular names ${ }^{[4]}$ :

English: Sausage Tree, Cucumber Tree, Hindi: Balamkheera, jhar fanus Kannada: 
Aanethoradu Kaayi, Mara Sowthae, Malayalam: Shiva Kundalam, Telugu: Kijili, Ngamalle.

\section{Habitat ${ }^{[5,6]}$ :}

It is grown in the rainforest, usually at wet sites and along rivers in wet forests. It is a tree that grows up to $20 \mathrm{~m}$ (66 feet) in height and generally has extended branches. The bark is initially gray and smooth, peeling older trees. It can have a thickness up to $6 \mathrm{~mm}$ ( 1 pollice 4 of an inch) on a branch of $15 \mathrm{~cm}$ of diameter the wood is light brown or yellowish, not differentiated and not subject to cracks.

\section{Morphology ${ }^{[7]}$ :}

Leaves: opposite or spirals 30 to $50 \mathrm{~cm}$ long, pinnate, with 6-10 oval leaflets, each up to $20 \mathrm{~cm}$ long and $6 \mathrm{~cm}$ wide.

Flowers: bisexual, very large; long stem up to $11 \mathrm{~cm}$ curved at the tip; chalice shaped tubular bell short 2 to $4.5 \mathrm{~cm}$ long, which widens and curves upward, limping with 2 lips, with superb or lip with 2 lobes, the lower with 3 lobes and curved.
Fruits: a large gray-brown fruit is a woody berry 30 to 100 $\mathrm{cm}$ long and up to $18 \mathrm{~cm}$ wide. It weighs between 4 and 10 $\mathrm{kg}$ and hangs on a long and fibrous stem. The fruit is fibrous and fleshy, and contains numerous hard seeds that are not edible for humans.

\section{Phytochemistry}

The consideration of the phytochemical components of medicinal plants such as K. Africana is vital not only for the understanding of the scientific basis for their use, but also for the discovery of new compounds of therapeutic value ${ }^{[8]}$. Several phytochemical studies have revealed that the extracts of Many Bignoniaceae species contained secondary metabolites such as saponins, tannins, flavonoids, quinone alkaloids, derivatives of anthralenes, reducing sugars, glycosides, carbohydrates, quercetin, kaempferol, $\beta$ sitosterol, terpene, steroids, secondary metabolites and their derivatives $[9,10,11]$

Table 1: Phytoconstituents in different parts of Kigelia africana plant

\begin{tabular}{|c|c|c|c|}
\hline Sr. no. & Part & constituents & Reference \\
\hline \multirow[t]{3}{*}{1} & Leaves & Hentriacontane, $\beta$ tocopherol, 3-hydro-4,8-phytene, 1,3,3,5,6,6-hexamethylcyclohexa-1,4-diene & 12 \\
\hline & & Lupeol, $\beta$ - Sitosterol, sitosteryl $\beta$-D-glucoside, canophyllol, pomolic acid, hydroxy-pomolic acid, & 13 \\
\hline & & $\begin{array}{l}\text { Caffeic acid, 7-hydroxy viteoid II, Polybotrin, Benzyl- } \beta \text {-D-glucopyranoside, Verminoside, Scutellarin 7- } \\
\text { O- } \beta \text {-D-glucopyranoside, }\end{array}$ & 14 \\
\hline \multirow[t]{3}{*}{3} & Fruits & $\beta$-friedelinol, fibrarecisin, sesamin, paulownin, & 13 \\
\hline & & iridoid glycosides, phenylpropanoid derivatives, and a eucommiol derivative. & 08,15 \\
\hline & & verminoside (iridoid), verbascoside(polyphenol) & 16 \\
\hline 4 & root & iridoids, naphthoquinones and coumarins, Elaidic acid, Lapachol & 17 \\
\hline 5 & $\begin{array}{l}\text { stem } \\
\text { bark }\end{array}$ & $\begin{array}{l}\text { iridoids specioside, verminoside and } \\
\text { minecoside }\end{array}$ & 18 \\
\hline
\end{tabular}<smiles>CCCCCCCCC=CCCCCCCCC(=O)O</smiles>

Elaidic acid<smiles>COc1cc2c(c(O)c1C)C(=O)OC(C)C2</smiles>

Kigelin

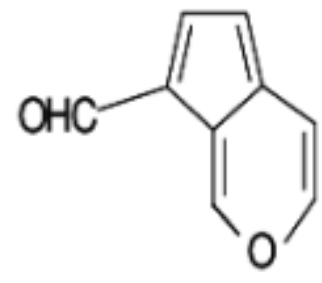

Norviburtinal<smiles>CC(C)=CCC1=C(O)C(=O)c2ccccc2C1=O</smiles>

Lapachol<smiles>CC[C@H](CC[C@@H](C)[C@]1(C)CCC2[C@H]3CC=C4CC(O)CC[C@]4(C)[C@H]3CC[C@]2(C)[C@H]1C)C(C)C</smiles>

Sitosterol 


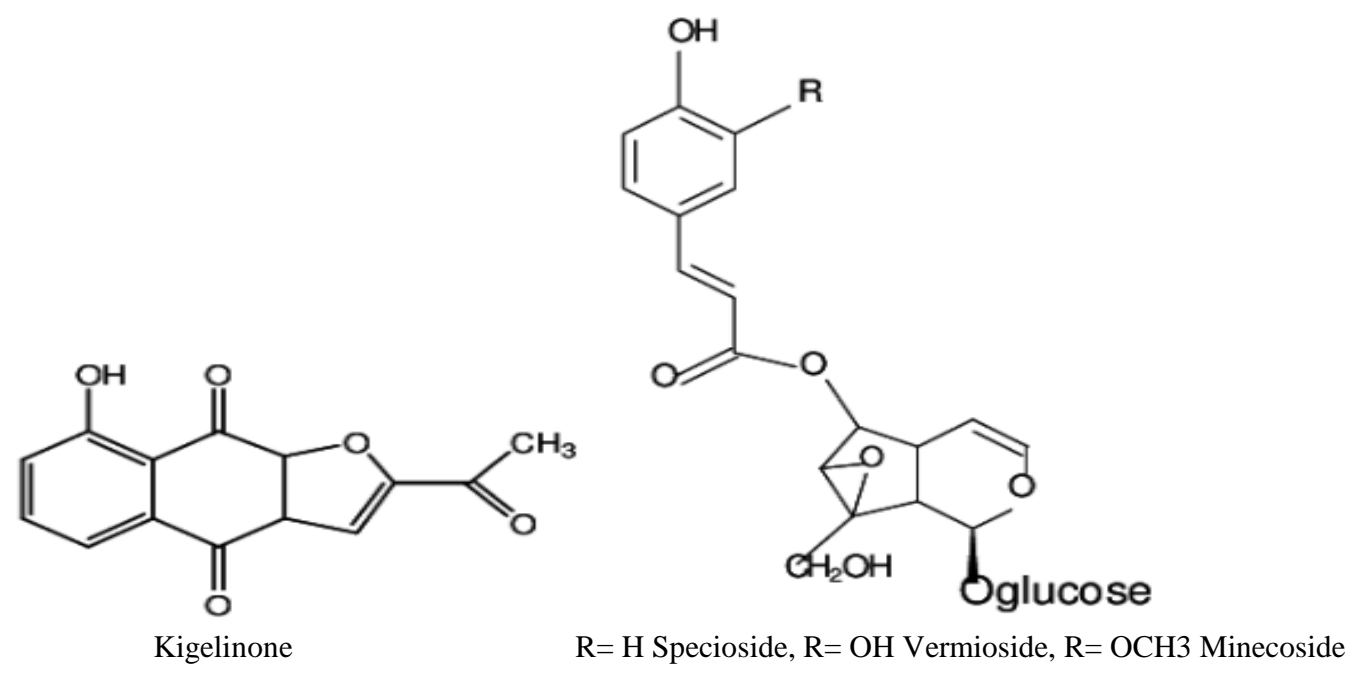

Fig 2: Some phytoconstituents of Kigelia Africana plant

\section{Pharmacology}

Anti-atherosclerotic effects

Kim HJ et al., 2018 studied the effects of the extract of Kigelia africana (Lam.), Focusing in particular on the antiatherosclerotic effects on endothelial cells (EC). Kigelia africana methanol extract showed no cytotoxicity in the EC at doses of $10 \sim 200 \mu \mathrm{g} / \mathrm{ml}$. At a concentration of $50 \mu \mathrm{g} /$ $\mathrm{ml}$ it showed a significant inhibition. The work concludes that it could be used for the treatment of atherosclerosis without cytotoxicity ${ }^{[19]}$.

\section{Anticonvulsant activity}

Singh A et al., $2010^{[20]}$ studied the anticonvulsant activity of methanolic (KPM) and aqueous (KPA) bark extracts of Kigelia pinnata using pentylene tetrazole and convulsions induced by maximum electroqueque in glycine rats. $250 \mathrm{mg}$ $/ \mathrm{kg}$ and $500 \mathrm{mg} / \mathrm{kg}$ of KPM and KPA showed a significant anticonvulsant effect by increasing the onset of clonic convulsions and decreasing the onset of tonic convulsions. ${ }^{20}$

\section{Antidiabetic and antioxidant activities}

Babu BH et al., $2019^{[21]}$ studied the antioxidant and antidiabetic activity of the Kigelia pinnata stem using 1,1diphenyl-2-picrylhydrazyl (DPPH) and the in vitro $\alpha$ amylase inhibition method, respectively. The inhibition of DPPH was tested for ethyl acetate, methanol, aqueous extracts. In Kigelia africana (stem), the aqueous extract found an IC50 at $20 \mu \mathrm{g} / \mathrm{ml}$ in the DPPH method and standard ascorbic acid shows DPPH IC50 at $20 \mu \mathrm{g} / \mathrm{ml}$. The aqueous extract shows an inhibition of $\alpha$-amylase IC50 at 15 $\mu \mathrm{g} / \mathrm{ml}$, while the standard acarbose drug shows an inhibition of $\alpha$-amylase IC50 at $20 \mu \mathrm{g} / \mathrm{ml}$. ${ }^{\text {[21] }}$

\section{Antifungal and antibacterial activities}

Owolabi OJ et al., $2007^{[22,27]}$ studied antibacterial and antifungal activity of Kigelia Africana stem bark. The results revealed that the crude ethanolic extract showed antibacterial and antifungal activity against Staphylococccus aureus and Candida albicans with zones of inhibition of 15.0 \pm 0.95 and $20.75 \pm 4.6 \mathrm{~mm}$ respectively. The aqueous extract showed no antibacterial or antifungal activity. The activities of the extracts have been compared with various standards; Ampicilina, Amoxicilina, Gentamicina, Ceftriaxona and Ciprofloxacin ${ }^{[22]}$.

\section{Anti-inflammatory activity}

Carey WM et al., 2008 [23] investigated the antiinflammatory effect of the methanolic extract of the Kigelia pinnata fruit using different in vivo inflammation models in mice and rats, such as formaldehyde-induced leg edema, acetic acid-induced vascular permeability. using cotton granules, estimation of plasma MDA levels and models of carrageenin-induced peritonitis. The dose of 100, 200 and $400 \mathrm{mg} / \mathrm{kg}$ of methanol extract of Kigelia pinnata showed an effect comparable to that of standard drugs ${ }^{[23]}$.

Mukesh R et al., 2012 reported anti-inflammatory activity of Kigelia pinnata leaf extract on Ratti Wistar. Through methods of leg edema induced by carrageenan and granuloma induced by cotton with indomethacin reference standard. The $200 \mathrm{mg} / \mathrm{kg}$ and $400 \mathrm{mg} / \mathrm{kg}$ dose of Kigelia pinnata leaf extract has a significant reduction in carrageenine-induced leg edema $(\mathrm{P}<0.001)$ in a dosedependent manner ${ }^{[24]}$.

Kamau JK et al., $2016^{[25]}$ studied the anti-inflammatory activity of the methanol extracts of Kigelia Africana using the carragen-induced posterior leg edema method with the reference drug diclofenac. The extract of the $\mathrm{K}$. africana leaf reduced the diameter of the inflamed hind paw of the mice by $0.21 \%-4.98 \%$. Diclofenac reduced the diameter of the inflamed hind paw to between $1.11 \%-4.9 \%$. The extracts were more active at a dose of $150 \mathrm{mg} / \mathrm{kg}$ body weight in the fourth hour of treatment ${ }^{[25]}$.

\section{Antimicrobial, antioxidant and wound healing}

Agyare C et al., $2013^{[26]}$ studied the antimicrobial and antioxidant properties of methanol leaf extracts and the cortex of the Kigelia Africana stem. The antimicrobial activities of the methanol extracts were determined against two Gram positive and two Gram negative bacteria and one fungus using micro and micro dilution diffusion methods. Antioxidant activity was determined using the 1, 1diphenyl-2-picryl-hydrazyl (DPPH) method. The influence of the extracts on the wound closure rate was studied using the excision injury model. The MIC of the extract of K. africana leaves against the examined organisms was 2.5-7.5 $\mathrm{mg} / \mathrm{ml}$ and the stem bark extract was $2.25-7.5 \mathrm{mg} / \mathrm{ml}$. Extracts of K. africana $(7.5 \% \mathrm{w} / \mathrm{w})$ showed a significant wound contraction $(P<0.05)$ on day 7 with a wound closure of $72 \%$ while significant wound contractions $(P<0,05)^{[26]}$. 


\section{Analgesic and anti-inflammatory.}

Owolabi OJ et al., $2007^{[22,27]}$ evaluated Kigelia Africana ethanol extract for its analgesic properties using acetic acid induced by acetic acid and the reaction time of hot plaque and anti-inflammatory properties using the edema method of legs induced by carrageenan. The extract of $\mathrm{K}$. africana showed a significant dose-dependent reduction in the number of twists $(\mathrm{P}<0.001)$ with a dose of $500 \mathrm{mg} / \mathrm{kg}$ of body weight which gave the greatest reduction. The extract of K. africana showed a significant dose-dependent reduction in the number of twists $(\mathrm{P}<0.001)$ with a dose of $500 \mathrm{mg} / \mathrm{kg}$ of body weight which gave the greatest reduction. The extract showed an insignificant elongation of the hot plate reaction time $(\mathrm{P}>0.05)$. Significant dosedependent inhibition was observed in carragen-induced leg edema ${ }^{[27]}$.

Carey MW et al., $2010^{[28]}$ studied the possible antiinflammatory and analgesic activities of the methanolic extract of the Kigelia pinnata flower. Anti-inflammatory activity performed in the model of carrageenan-induced leg edema in rats and analgesic activity in models of leg licking induced by acetic acid, heating plate and induction of formalin in mice. The extract showed anti-inflammatory and analgesic activity with doses of 100, 200 and $400 \mathrm{mg} / \mathrm{kg}$ of body weight. in rats and mice respectively ${ }^{[28]}$.

\section{Antineoplastic activity}

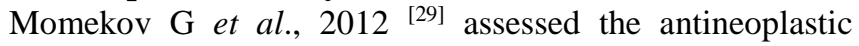
activity of a total methanolic extract from the stem bark of Kigelia pinnata using in vitro testing included cytotoxicity (MTT assay) and pro-apoptotic activity investigation. The extract displayed prominent cytotoxicity against a panel of human tumor cell lines and exerted strong antineoplastic activity against Lewis lung carcinoma with prominent increase of the life span of treated animals and tumor growth inhibition ${ }^{[29]}$.

\section{Antioxidant and antimicrobial activity}

Olubunmi A et al., $2009{ }^{\text {[30] }}$. antimicrobials in a Gram positive (Staphylococcus aureus), two Gram negative bacteria strains (Klebsiella pneumonia, Salmonella typhi) and two fungi (Candida albicans and Trichophyton mentagrophyte) using tetracycline as standard antibiotics [30].

Abere TA et al., $2015^{[31]}$ studied the antioxidant activity of using different fractions of Kigelia pinnata leaf extracts with the DPPH radical scavenging method. The polyphenolic contents were also evaluated. The inhibitory activity of the crude methanol extract and the fractions against the clinical strains of Escherichia coli, Bacillus subtilis, Staphylococcus aureus, Pseudomonas aeruginosa, Klebsiella aerogenes, Candida albicans and Candida parasilopsis were compared respectively with ciprofloxacin and nystatin for bacteria and fungi. The N-butanol fraction showed the maximum antioxidant activity. The extract and the crude methanol fractions inhibited the growth of E. coli, B. subtilis, S. aureus, P. aeruginosa, C. albicans and C. parasilopsis at various levels, with the exception of the aqueous fraction without activity ${ }^{[31]}$.

\section{Antiamobic activity}

Bharti $\mathrm{N}$ et al., $2006^{[18]}$ studied the in vitro antiamobic evaluation of isolated iridoids, such as speciosid, verminoside and minecoside. Metronidazole used as a reference standard. Verminoside showed a double antiamobic activity compared to the standard drug, while the spicy one showed an activity comparable to metronidazole [18].

\section{Antioxidant and anticancer activity}

Olubunmi et al., $2013^{[32]}$ studied isolated fractions of leaf extract for antioxidant and cytotoxic activity. Antioxidant activity performed by in vitro techniques such as reducing ferric antioxidant power (FRAP), elimination of 2,2diphenyl-1-picrylhydrazyl radicals (DPPH) and 2,2-azinobis acid (3-ethyl-benzothiazoline acid -6 test 'sulfonic acid (ABTS). The cytotoxic activity was evaluated in human rhabdomyosarcoma tumor cells to determine their cytotoxicity using 3- (4.5-dimethylthiazol-2-yl) -2 bromide cell viability assays. 5-diphenyltetrazolium (MTT) with reference cyclophosphamide the methanol extract was richer in phenol and was more potent as an antioxidant and cytotoxic agent among all the substances analyzed the relatively high cytotoxicity index was found to be extracted from acetate ethyl ${ }^{[32]}$.

\section{Anticonvulsant activity, anxiolytic activity and effect on motor coordination.}

Dhanasekaran. M et al 2014 [33] studied extracts of petroleum ether, chloroform and methanol obtained from Kigelia Africana leaves using the animal model of Wistar of albino rat for anticonvulsant activity, anxiolytic activity and effect on motor coordination activity. The discovery revealed that the plant can be used as a nervous tonic ${ }^{[33]}$.

\section{Antimicrobial activity}

Abdulkadir MN et al., $2015^{[34]}$ studied the antimicrobial activity of petroleum ether, chloroform, methanol and aqueous extracts of Kigelia africana against Candida albicans, Escherichia coli, Klebsiella pneumonia, Pseudomonas aeruginosa, Streptococcus feacalis and Staphylococcus a. Petroleum ether extract showed dosedependent antibacterial activity against Candida albicans and Pseudomonas aeruginosa. Chloroform extract showed a dose-dependent activity against Streptococcus feacalis and Staphylococcus aureus. The methanol extract and the aqueous extract were active only against Staphylococcus aureus ${ }^{[34]}$.

\section{Anti-urolithic activity}

Kumar S et al., 2012 [35] evaluated the ethanol extract of the Kigelia pinnata fruit against ethylenic glycol-induced urolithiasis in rats using cistone as a standard anti-urolithic drug. The antiurolytic activity of the Kigelia pinnata fruit extract was studied by measuring the serum marker (creatinine and uric acid), the homogenized tissue marker (calcium, oxalate and phosphate), the urinary parameter (calcium, oxalate, phosphate, uric acid and magnesium) and urine production is therefore significantly reduced and prevented the growth of urinary calculi ${ }^{[35]}$.

\section{Cardioprotective activity}

Yalu H et al., $2015^{[36]}$ studied the cardioprotective activity of Kigelia Africana leaves in myocardial infarction induced by isoprenaline with propranolol as a reference standard. $100 \mathrm{mg} / \mathrm{kg}, 200 \mathrm{mg} / \mathrm{kg}$ of methanol extract from the leaves of Kigelia Africana showed a significant reduction in the serum marker enzymes aspartate transaminase (AST), 
lactate dehydrogenase (LDH), alanine transaminase (ALT), alkaline phosphatase (ALP), changes in markers of oxidative stress such as lipid peroxidase (LPO), glutathione (GSH), catalase (CAT) and superoxide dismutase (SOD) caused by ISO (5.25 and $8.5 \mathrm{mg} / \mathrm{kg})^{[36]}$.

\section{Diuretic activity}

Agarwal V et al., $2010^{[37]}$ studied the diuretic activity of aqueous Kigelia pinnata bark extract in experimental rats. The diuretic properties were evaluated by determining the volume of urine, the concentration of electrolytes and the diuretic power in male albino rats. Different concentrations (250 mg / kg, $500 \mathrm{mg} / \mathrm{kg}$ ) were administered orally to hydrated rats and their urine production was measured immediately after 5 hours of treatment with Frusemide as a reference drug. $500 \mathrm{mg} / \mathrm{kg}$ showed that the highest activity with a power value of 0.80 caused an increase in the $\mathrm{Na}+$, $\mathrm{K}+$ and $\mathrm{Cl}$ signs ${ }^{[37]}$.

\section{Hypoglycemic activity}

Njogu SM et al., $2018^{[38]}$ studied the in vivo hypoglycaemic activity of aqueous extracts and ethyl acetate of African Kigelia leaves using the Alloxan-induced diabetes model. The study showed that the aqueous extracts and ethyl acetate leaf of African $\mathrm{K}$ had antidiabetic activity when therapeutic doses were administered both intraperitoneally and orally in both fractions ${ }^{[38]}$.

\section{Spasmolytic and antidiarrheal effects}

Otimenyin SO and Uzochukwu DC 2010 have studied the spasmolytic and antidiarrheal effects of K. Africana cortex using in vivo castor oil that induces the diarrhea model in rats and in rabbit isolated fast in vitro. $\mathrm{K}$. africana (500 and $1000 \mathrm{mg} / \mathrm{kg})$ significantly reduced $(\mathrm{P}<0.05)$ the frequency of diarrhea in the faeces and the spontaneous propulsive movement of the isolated rabbit fasting (anti-motility) ${ }^{[39]}$.

\section{Conclusion}

The review reveals that Kigelia Africana (Bignoniaceae) was found to be a powerful analgesic, anti-inflammatory, CNS depressant, anthelmintic, antibacterial, antifungal and cytotoxic. The chemical components present in the plant are mainly tannins, terpenoids, saponins and flavonoids which are responsible for the actions. Further research is needed to isolate the components responsible for the required therapeutic activities. This review concludes that the plant has a high medicinal value.

Therefore, by using reverse pharmacological approaches in the discovery of natural drugs, it is possible to study a powerful and safe plant drug for various chronic diseases such as diabetes, liver disease, arthritis, cancer and inflammatory diseases.

\section{References}

1. Morales F, Padilla S, Falconi F. medicinal plants used in traditional herbal medicine in the province of Chimborazo, Ecuador, Afr J Tradit Complement Altern Med., 2017; 14(1):10-15. doi:10.21010/ajtcam. v14i1.2.

2. Thomas SC. Medicinal plants culture, utilization and phytopharmacology, Li. United States: CRC Press; 1995, 119-54.

3. Fredrick AC, Ebele OP, Chioma Obi, Utoh-Nedosa UA. Analgesic, Phytochemical and Toxicological investigations of ethanol extract of the leaves of Kigelia africana (Lam.) Benth (family Bignoniaceae)-Sausage Tree. J Pharm Biomed Sci. 2014; 04(07):588-595.

4. Sausage Tree, http://www.flowersofindia.net/catalog/slides/Sausage\% 20Tree.

5. Burkil HM. The useful plants of west tropical Africa, Royal botanic garden kew, 1985, 2004.

6. Huxley A, Kigelia. In The New RHS Dictionary of Gardening 2, Macmillan. 1992, 735.

7. Elhasan GO, omer SM, Khan MU, Abdulkareem AM, Khalilullah H. Kigelia africana: an ephemeral glance, International Journal of Pharmacology and Pharmaceutical Sciences. 2014; 2(2):20-25.

8. Gouda YG, Abdel-Baky AM, Darwish FM, Mohamed KM, Kasai R, Yamasaky K. Phenylpropanoid and phenylethanoid derivatives From Kigelia pinnata D.C. Fruits. Nat. Prod. Res. 2006; 10:935-939.

9. Choudhury S, Datta S, Talukdar AD, Choudhury MD. Phytochemistry of the Bignoniaceae-A review. Biol. Environ. Sci. 2011; 1:145-150.

10. Govindachari TR, Patankar SJ, Viswanathan N. Isolation and structure of two new dihydroisocoumarins from Kigelia pinnata. Phytochem. 1971; 10:1603-1606. Cited by Oliver-Bever B, in Medicinal plants in Tropical West Africa. Cambridge, UK: Cambridge University Press, 1986.

11. Sayyad SM. Flavonoids of the leaves and fruits of Kigelia pinnata. Fitoterapia. 1982; 42:189-191.

12. Atolani O, Oladoye S, Oluyori AP, Olatunji AG. New Constituents of Kigelia pinnata Leaves. Singapore Journal of Scientific Research. 2012; 2:47-53.

13. Lazare SS, Raduis M, Valerie ML, Gaetan H, Tchinda AT, Ollivier E et al. Triterpenes and Lignans from Kigelia african, Journal of Applied Pharmaceutical Science, 2015; 5(2):001-006.

14. Kapil E, Ramakrishna E, Maurya M, Kothari P, Tripathi A. Phytochemical investigation of Kigelia pinnata leaves and identification of osteogenic agents, Medicinal Chemistry Research, Springer US, 2017, 1-6, doi:10.1007/s00044-017-1807-z.

15. Gouda Y, Abdel-baky A, Darwish F, Mohammed K, Kasai R, Yamasaki K. Iridoids for Kigelia pinnata DC. Fruits. Phytochemistry. 2003; 63:887-892.

16. Costa R, Albergamo A, Pellizzeri V, Dugo G. Phytochemical screening by LC-MS and LC-PDA of ethanolic extracts from the fruits of Kigelia africana (Lam.) Benth, Natural Product Research, 2016, 1-6, doi: 10.1080/14786419.2016.1253080.

17. Atolani O, Adeyemi SO, Akpan E, Adeosun CB, Olatunji GA. chemical composition and antioxidant potentials of Kigelia pinnata root oil and extracts, EXCLI Journal 2011;10:264-273.

18. Bharti N, Singh S, Naqvi F, Azam A. Isolation and in vitro antiamoebic activity of iridoids isolated from Kigelia pinnata. ARKIVOC. 2006, 69-76.

19. Ko YS, Nash O, Choi S, Kim HJ. Methanolic extract of Kigelia africana exhibits antiatherosclerotic effects in endothelial cells by downregulating RAGE and adhesion molecules, Tropical Biomedicine. 2019; 36(1):172-182.

20. Singh A, Sharma UK, Sharma U, Sutar N, Misra V, Yadav G. Anticonvulsant activity of Kigelia pinnata bark extracts. Int J Pharm Pharm Sci. 2010; 2:147-9. 
21. Swarnalatha K, Venkata Kishore $\mathrm{CH}$, Babu $\mathrm{BH}$. phytochemical screening, anti-diabetic and antioxidant Activities of Kigelia africana (LAM.) and Sterculia foetida L. Rasayan J Chem., 2019; 12(2):907-914. doi.org/10.31788/RJC.2019.1225168.

22. Owolabi OJ, Omogbai EKI, Obasuyi O. Antifungal and antibacterial activities of the ethanolic and aqueous extract of Kigelia africana (Bignoniaceae) stem bark. Afr J Biotechnol. 2007; 6:1677-1680.

23. Carey MW, Babu MJD, Rao VN. Anti-inflammatory activity of the fruit of Kigelia pinnata DC. Pharmacologyonline. 2008; 2:234-245.

24. Parmar N, Rawat M, Tirath K. Evaluation of antiinflammatory potential of kigelia pinnata leaf extract in wistar rats, Asian J Pharm Clin Res, 2012; 5(1):95-97.

25. Kamau JK, Nthiga PM, Mwonjoria JK, Ngeranwa JJN, Ngugi MP. Anti-Inflammatory Activity of Methanolic Leaf Extract of Kigelia Africana (Lam.) Benth and Stem Bark Extract of Acacia Hockii De Wild in Mice. J Dev Drugs. 2016; 5:156. doi:10.4172/23296631.1000156.

26. Agyare C, Dwobeng AS, Agyepong N, Boakye YD, Mensah KB, Ayande PG et al. Antimicrobial, antioxidant, and wound healingproperties of Kigelia africana (Lam.) beneth. and Strophanthus hispidus DC. Adv Pharmacol Sci. 2013; 2013:692613.

27. Owolabi OJ, Omogbai EKI. Analgesic and antiinflammatory activities of the ethanolic stem bark extract of Kigelia africana (Bignoniaceae, African Journal of Biotechnology 2007; 6(5):582-585 .

28. Carey MW, Rao NV, Kumar BR, Mohan GK. Antiinflammatory and analgesic activities of methanolic extract of Kigelia pinnata DC flower. J Ethnopharmacol. 2010; 130:179-82.

29. Momekova D, Momekov G, Pencheva I, Konstantinov $\mathrm{S}$. Antineoplastic activity of a methanolic extract from Kigelia pinnata DC stem bark, Journal of Cancer Therapeutics \& Research, 2012, 1-7.

30. Olubunmi A, Gabriel OA, Stephen AO, Scott FO. Antioxidant and Antimicrobial Activity of Cuticular Wax from Kigelia africana, FABAD J. Pharm. Sci., 2009; 34:187-194.

31. Abere TA, Asemu KA, Umhenin GE. Pharmacognostic, antioxidant and antimicrobial activity of fractions of the leaf extract of Kigelia africana Lam. Benth (Bignoniaceae) IOSR Journal Of Pharmacy. 2015; 5, (6):43-51

32. Olubunmi A, Olatunji GA, Fabiyi OA, Adeniji AJ, Ogbole OO. Phytochemicals from Kigelia pinnata Leaves Show Antioxidant and Anticancer Potential on Human Cancer Cell Line J Med Food. 2013; 16(10):878-885.

33. Dhanasekaran M, Abraham GC, Mohan S. The evaluation of Pharmacological potential on Kigelia pinnata DC. International Journal of Pharma Sciences and Research. 2014; 5(08):489-494.

34. Abdulkadir MN, Adedokun A, John E. Phytochemical composition and antimicrobial evaluation of Kigelia africana LAM. Asian Journal of Plant Science and Research. 2015; 5:14-17.

35. Kumar S, Kumar V, Prakash OM. Antidiabetic and hypolipidemic activities of Kigelia pinnata flowers extract in streptozotocin induced diabetic rats. Asian Pac J Trop Biomed. 2012; 2:543-546.
36. Nagarathna PKM, Yalu H, Mondal LR. Cardioprotective Activity of Leaves of Kigelia Africana on Isoprenaline Induced Myocardial Infarction. International Journal of Ayurveda and Pharma Research. 2015; 3(3):44-53.

37. Agarwal V, Sharma UK, Sharma US, Singh A. Diuretic activity of kigelia pinnata bark extract, Journal of Pharmacology Research, 2010; 1(2):17-20.

38. Njogu SM, Arika WM, Machocho AK, Ngeranwa JJM, Njagi ENM. In vivo Hypoglycemic Effect of Kigelia africana (Lam): Studies With Alloxan-Induced Diabetic Mice, Journal of Evidence-Based Integrative Medicine. 2018; 23:1-10.

39. Otimenyin SO, Uzochukwu DC. Spasmolytic and Antidiarrhea effects of the bark of Erythrina senegalensis and root of Kigelia africana, Asian J Pharm Clin Res. 2012; 3(4):11-14. 